\title{
THE SYNTHESIS AND IN SILICO ANTIHYPERTENSIVE ACTIVITY PROGNOSIS OF NEW MANNICH BASES CONTAINING THE 1,2,4-TRIAZOLE MOIETY
}

\author{
Lina Perekhoda ${ }^{1}$, Victoria Georgiyants ${ }^{1}$, Hanna Yeromina ${ }^{1}{ }^{凶}$, Iryna Drapak $^{2}$, \\ Vira Lubenets ${ }^{3}$, Zinaida Ieromina1, Irina Sych ${ }^{1}$, Hanna Severina1, Anatoly Demchenko ${ }^{4,5}$
}

https://doi.org/10.23939/chcht14.02.214

\begin{abstract}
As a part of our continuous research on potential antihypertensive agents among morpholine and piperidine derivatives, 10 novel target compounds containing 1,2,4-triazole and morpholine or piperidine moieties have been designed and synthesized, and the docking studies have been conducted in order to find biologically active substances with the antihypertensive activity. The in silico studies have shown that all compounds synthesized are promising angiotensin converting enzyme inhibitors and belong to the toxicity class 4 and 5 according to the classification of chemicals by the OECD project.
\end{abstract}

Keywords: Mannich bases, 1,2,4-triazole, synthesis, antihypertensive activity, in silico prognosis, docking studies.

\section{Introduction}

1,2,4-Triazole, morpholine and piperidine derivatives are regarded as an important heterocyclic motif that exhibits a wide range of biological activity, including antiviral, antibacterial, antitumor, antidepressant, antihypertensive, antioxidant, etc. [1-7]. In view of their wide-ranging activities the synthesis of 1,2,4-triazole, morpholine and piperidine and their derivatives remain the primary focus for synthetic chemistry communities.

Morpholine is a simple heterocyclic compound, a saturated heterocyclic secondary amine that has a great

\footnotetext{
${ }^{1}$ National University of Pharmacy, 53, Pushkinska St., Kharkiv, Ukraine

${ }^{2}$ Danylo Halytsky Lviv National Medical University,

69, Pekarska St., Lviv, Ukraine

${ }^{3}$ Lviv National Polytechnic University,

12, S. Bandery Str., 79013 Lviv, Ukraine

${ }^{4}$ Institute of Pharmacology and Toxicology, National Academy of

Medical Sciences, 14, Anton Tsedik St., Kyiv, Ukraine

${ }^{5}$ Nizhyn Mykola Gogol State University,

2, Grafskaya Str., Nizhyn, Ukraine

annerem2012@gmail.com

(c) Perekhoda L., Georgiyants V., Yeromina H., Drapak I., Lubenets

V., Ieromina Z., Sych I., Severina H., Demchenko A., 2020
}

industrial importance and a wide range of applications [811]. This chemical compound and its derivatives have been used in the manufacture of a number of drugs, such as antioxidants, membrane stabilizers, hepato- and cardioprotectors (Thiotriazoline), antimycobacterial (Rifampicin), antibacterial (Linezolid) drugs, etc. [12].

Piperidine is a simple heterocyclic compound and a saturated heterocyclic secondary amine too. The piperidine moiety is a ubiquitous structural feature of many natural products [13-14]. Numerous useful compounds contain the piperazine derivatives in drug molecules, especially those with substitution on the nitrogen atoms. Among the examples are antihistamine and anticholinergic drug Cyclizine, antidepressant Amoxapine, antiischemic Trimetazidine, antipsychotic drug Bifeprunox, and anticovulsant Ropizine. The piperazine moiety is also presented in antihypertensive agents. Prazosin is a selective $\alpha$-adrenergic receptor antagonist used to treat hypertension and benign prostatic hyperplasia, Flunarizine is a calcium channel blocker, Oxatomide is an $\mathrm{H}_{1}$-antihistaminic drug that also inhibits mediator release from mast cells, Ranolazine is an antianginal agent [14].

1,2,4-Triazole compounds containing three nitrogen atoms in the five-membered aromatic azole ring are readily able to bind with a variety of enzymes and receptors in a biological system via diverse non-covalent interactions and are a ubiquitous structural feature of many synthetic compounds with diversified therapeutic efficacy [7, 15-18]. Some of the present-day drugs, such as Ribavirin (antiviral agent), Rizatriptan (antimigraine agent), Alprazolam (anxiolytic agent), Itraconazole, and Fluconazole (antifungal agents) are the best examples for potent molecules possessing the triazole nucleus.

In view of this, the aim of our work was to combine these scaffolds in one structure in order to find biologically active substances with the antihypertensive activity using docking studies and predict the possible acute toxicity using the GUSAR-prognosis. 


\section{Experimental}

\subsection{Chemistry}

All solvents were purified before use. Morpholin4-amine, piperidine-4-amine, formaldehyde, substituted 1,2,4-triazoles were purchased from Acros Organics and used without purification. Reactions were monitored by thin-layer chromatography (TLC) using Fluka silica gel (60 F 254) plates $(0.25 \mathrm{~mm})$. Visualization was made with UV light. Melting points of the compounds synthesized were determined by the Kofler method. Elemental analysis was performed on an EuroEA 3000 elemental analyzer. ${ }^{1} \mathrm{H}$ NMR spectra were recorded on a Varian Gemini $400 \mathrm{MHz}$ device in DMSO-d6 using tetramethylsilane (TMS) as an internal standard. ${ }^{13} \mathrm{C}$ NMR spectra were recorded on a Varian MR-400 device in DMSO- $\mathrm{d}_{6}$ using TMS as an internal standard. Chemical shifts were reported in ppm units of the $\delta$ scale.

\subsection{General Procedure of the Synthesis of Substituted 1,2,4-Triazole-3-Thiones}

\section{1-4.10}

To the solution of $0.05 \mathrm{~mol}$ the corresponding amount of 1,2,4-triazole 1.1-1.10 in $20 \mathrm{ml}$ of ethanol and $1.5 \mathrm{ml}$ of $40 \%$ formaldehyde 3 solution were added under stirring at $293 \mathrm{~K}$. Then $0.01 \mathrm{~mol}$ of the corresponding secondary amine 2 was added. The reaction mixture was stirred for $1 \mathrm{~h}$. Then it was kept overnight at room temperature. The resulting precipitate was filtered, purified by crystallization from ethanol, and dried.

\section{3-thione 4.1}

2-(Morpholinomethyl)-4,5-diphenyl-1,2,4-triazole-

Yield $76 \%$, mp 461-462 K. ${ }^{1} \mathrm{H}$ NMR $(400 \mathrm{MHz}$, DMSO-d $\left.\mathrm{d}_{6}\right) \delta: 2.70\left(\mathrm{~m}, 4 \mathrm{H}, \mathrm{CH}_{2} \mathrm{NCH}_{2}\right), 3.60(\mathrm{~m}, 4 \mathrm{H}$, $\left.\mathrm{CH}_{2} \mathrm{OCH}_{2}\right), 5.15\left(\mathrm{~s}, 2 \mathrm{H}, \mathrm{N}-\mathrm{CH}_{2}-\mathrm{N}\right), 7.20-7.60(\mathrm{~m}, 10 \mathrm{H}$, 2Ph). ${ }^{13} \mathrm{C}$ NMR $\quad\left(100 \mathrm{MHz}, \quad\right.$ DMSO-d $\left.\mathrm{d}_{6}\right) \quad \delta: \quad 58.60$ $\left(\mathrm{CH}_{2} \mathrm{NCH}_{2}\right), 58.80\left(\mathrm{CH}_{2} \mathrm{OCH}_{2}\right), 67.58\left(\mathrm{~N}-\mathrm{CH}_{2}-\mathrm{N}\right), 126.6$ (C), $127.6(2 \mathrm{C}), 128.5(2 \mathrm{C}), 128.8(2 \mathrm{C}), 130.3(\mathrm{CH})$, 131.3 (C), 131.7 (2C), 139.6 (N-C), 145.3 (C-Ph), 159.4 $(\mathrm{C}=\mathrm{S})$. Anal.Calcd. for $\mathrm{C}_{19} \mathrm{H}_{22} \mathrm{~N}_{4} \mathrm{OS}, \% \mathrm{~N}$ 15.90; $\mathrm{S} 9.10$. Found, \% N 15.9; $\mathrm{S} 9.21$.

5-(4'-Bromophenyl)-4-phenyl-2-

(morpholinomethyl)-1,2,4-triazole-3-thione $\mathbf{4 . 2}$

Yield 70\%, mp 464-466 K. ${ }^{1} \mathrm{H}$ NMR (400 MHz, DMSO-d $\left.\mathrm{d}_{6}\right) \delta: 2.60\left(\mathrm{~m}, 4 \mathrm{H}, \mathrm{CH}_{2} \mathrm{NCH}_{2}\right), 3.60(\mathrm{~m}, 4 \mathrm{H}$, $\left.\mathrm{CH}_{2} \mathrm{OCH}_{2}\right), 5.15\left(\mathrm{~s}, 2 \mathrm{H}, \mathrm{N}-\mathrm{CH}_{2}-\mathrm{N}\right), 7.20-7.50$ (d-d, 4H, $\left.\mathrm{C}_{6} \mathrm{H}_{4}\right), 7.30$ (m, 5H, Ar). ${ }^{13} \mathrm{C}$ NMR (100 MHz, DMSO-d $\left.\mathrm{d}_{6}\right)$ $\delta$ : $58.50\left(\mathrm{CH}_{2} \mathrm{NCH}_{2}\right), 58.70\left(\mathrm{CH}_{2} \mathrm{OCH}_{2}\right), 67.45\left(\mathrm{~N}-\mathrm{CH}_{2}-\right.$ $\mathrm{N}), 124.2(\mathrm{Br}-\mathrm{C}), 126.5(\mathrm{C}), 127.6(2 \mathrm{C}), 128.5(2 \mathrm{C}), 129.9$ (C), 131.0 (2C), 132.5 (2C), $139.5(\mathrm{~N}-\mathrm{C}), 145.2$ (C), $159.3(\mathrm{C}=\mathrm{S})$. Anal.Calcd for $\mathrm{C}_{19} \mathrm{H}_{19} \mathrm{BrN}_{4} \mathrm{OS}, \% \mathrm{~N}$ 12.99;
S 7.43. Found, \% N 13.2; S 7.52.

5-Benzyl-4-phenyl-2-(morpholinomethyl)-1,2,4triazole-3-thione $\mathbf{4 . 3}$

Yield $59 \%$, mp $397 \mathrm{~K} .{ }^{1} \mathrm{H} \mathrm{NMR} \quad(400 \mathrm{MHz}$, DMSO- $\left.\mathrm{d}_{6}\right) \delta: 2.82\left(\mathrm{~m}, 4 \mathrm{H}, \mathrm{CH}_{2} \mathrm{NCH}_{2}\right), 3.60\left(\mathrm{~s}, 2 \mathrm{H}, \mathrm{CH}_{2}-\right.$ $\mathrm{Ph}), 3.64\left(\mathrm{~m}, 4 \mathrm{H}, \mathrm{CH}_{2} \mathrm{OCH}_{2}\right), 3.86\left(\mathrm{~s}, 2 \mathrm{H}, \mathrm{CH}_{2}\right), 5.08(\mathrm{~s}$, $\left.2 \mathrm{H}, \mathrm{N}-\mathrm{CH}_{2}-\mathrm{N}\right), 6.80-7.52(\mathrm{~m}, 10 \mathrm{H}, 2 \mathrm{Ph}) .{ }^{13} \mathrm{C} \mathrm{NMR}$ $\left(100 \mathrm{MHz}, \quad \mathrm{DMSO}-\mathrm{d}_{6}\right) \quad \delta: 34.68 \quad\left(\mathrm{C}^{\left.-\mathrm{CH}_{2} \mathrm{C}\right)}, \quad 58.62\right.$ $\left(\mathrm{CH}_{2} \mathrm{NCH}_{2}\right), 58.83\left(\mathrm{CH}_{2} \mathrm{OCH}_{2}\right), 67.51\left(\mathrm{~N}-\mathrm{CH}_{2}-\mathrm{N}\right), 126.2$ (C), 127.0 (C), 127.4 (2C), 127.75 (2C), 127.8 (C), 131.2 (2C), 136.1(C), 139.9 (N-C), 146.5 (C), $151.2(\mathrm{C}=\mathrm{S})$. Anal. Calcd. for $\mathrm{C}_{20} \mathrm{H}_{22} \mathrm{~N}_{4} \mathrm{OS}, \% \mathrm{~N}$ 15.29; $\mathrm{S}$ 8.75. Found, $\% \mathrm{~N} 15.4$; S 8.89.

5-(4-Bromophenyl)-4-(4'-ethoxyphenyl)-2-

(morpholinomethyl)-1,2,4-triazole-3-thione $\mathbf{4 . 4}$

Yield $65 \%$, mp 454-455 K. ${ }^{1} \mathrm{H}$ NMR $(400 \mathrm{MHz}$, DMSO- $\left.\mathrm{d}_{6}\right) \delta: 1.35\left(\mathrm{t}, 3 \mathrm{H}, \mathrm{OCH}_{2} \mathrm{CH}_{3}\right), 2.60(\mathrm{~m}, 4 \mathrm{H}$, $\mathrm{CH}_{2} \mathrm{NCH}_{2}$ ), 3.55 (m, 4H, $\left.\mathrm{CH}_{2} \mathrm{OCH}_{2}\right), 4.05$ (q, 2H, $\left.\mathrm{OCH}_{2} \mathrm{CH}_{3}\right), 5.15\left(\mathrm{~s}, 2 \mathrm{H}, \mathrm{N}-\mathrm{CH}_{2}-\mathrm{N}\right), 7.00-7.60(\mathrm{~m}, 4 \mathrm{H}$, $\left.\mathrm{C}_{6} \mathrm{H}_{4}\right) .{ }^{13} \mathrm{C}$ NMR (100 MHz, DMSO-d 6$) \delta: 14.68\left(\mathrm{CH}_{3}\right)$, $58.51\left(\mathrm{CH}_{2} \mathrm{NCH}_{2}\right), 58.83\left(\mathrm{CH}_{2} \mathrm{OCH}_{2}\right), 63.62\left(\mathrm{OCH}_{2}\right)$, $67.53\left(\mathrm{~N}-\mathrm{CH}_{2}-\mathrm{N}\right), 115.3(2 \mathrm{C}), 124.2(\mathrm{Br}-\mathrm{C}), 129.9(\mathrm{C})$, 130.4 (2C), $130.8(2 \mathrm{C}), 132.5(2 \mathrm{C}), 133.8(\mathrm{~N}-\mathrm{C}), 145.3$ (C), $154.9 \quad(\mathrm{C}-\mathrm{O}), \quad 159.4 \quad(\mathrm{C}=\mathrm{S})$. Anal.Calcd. for $\mathrm{C}_{21} \mathrm{H}_{23} \mathrm{BrN}_{4} \mathrm{O}_{2} \mathrm{~S}, \% \mathrm{~N}$ 11.78; $\mathrm{S}$ 6.74. Found, \% N 12.0; $\mathrm{S}$ 7.01 .

5-[(2',4'-Dichlorophenoxy) methyl]-4-penyl-2-

(morpholinomethyl)-1,2,4-triazole-3-thione $\mathbf{4 . 5}$

Yield $67 \%$, mp 483-484 K. ${ }^{1} \mathrm{H}$ NMR $(400 \mathrm{MHz}$, DMSO- $\left._{6}\right) \delta: 3.02\left(\mathrm{~m}, 4 \mathrm{H}, \mathrm{CH}_{2} \mathrm{NCH}_{2}\right), 3.60(\mathrm{~m}, 4 \mathrm{H}$, $\left.\mathrm{CH}_{2} \mathrm{OCH}_{2}\right), 5.02\left(\mathrm{~s}, 2 \mathrm{H}, \mathrm{CH}_{2}\right), 5.08\left(\mathrm{~s}, 2 \mathrm{H}, \mathrm{N}-\mathrm{CH}_{2}-\mathrm{N}\right)$, 7.11-7.54 (m, 8H, Ph+ $\left.\mathrm{C}_{6} \mathrm{H}_{3}\right) .{ }^{13} \mathrm{C} \mathrm{NMR} \quad(100 \mathrm{MHz}$, DMSO-d $\left.{ }_{6}\right) \delta: 58.57 \quad\left(\mathrm{CH}_{2} \mathrm{NCH}_{2}\right), 58.78\left(\mathrm{CH}_{2} \mathrm{OCH}_{2}\right)$, $67.47\left(\mathrm{~N}-\mathrm{CH}_{2}-\mathrm{N}\right), 69.28\left(\mathrm{O}-\mathrm{CH}_{2}\right), 115.9(\mathrm{C}), 122.3(\mathrm{Cl}-$ C), 125.5 (2C), 127.2 (C), 127.4 (2C), 127.9 (2C), 130.0(C), $130.4(\mathrm{Cl}-\mathrm{C}), 138.9(\mathrm{~N}-\mathrm{C}), 146.3$ (C), 152.9 (C-O), $163.9(\mathrm{C}=\mathrm{S})$. Anal. Calcd. for $\mathrm{C}_{20} \mathrm{H}_{20} \mathrm{Cl}_{2} \mathrm{~N}_{4} \mathrm{O}_{2} \mathrm{~S}, \%$ $\mathrm{N} 12.41$; $\mathrm{S} 7.10$. Found, \% N 12.5; S 7.19.

5-Phenyl-4-(m-tolyl)- 2-( morpholinomethyl)-1,2,4triazole-3-thione 4.6

Yield $69 \%$, mp 458-459 K. ${ }^{1} \mathrm{H}$ NMR $(400 \mathrm{MHz}$, DMSO- $\left.\mathrm{d}_{6}\right) \delta: 2.35\left(\mathrm{~s}, 3 \mathrm{H}, \mathrm{CH}_{3}\right), 2.70\left(\mathrm{~m}, 4 \mathrm{H}, \mathrm{CH}_{2} \mathrm{NCH}_{2}\right)$, $3.60\left(\mathrm{~m}, 4 \mathrm{H}, \mathrm{CH}_{2} \mathrm{OCH}_{2}\right), 5.15\left(\mathrm{~s}, 2 \mathrm{H}, \mathrm{N}-\mathrm{CH}_{2}-\mathrm{N}\right), 7.20$ $7.40(\mathrm{~m}, 9 \mathrm{H}, \mathrm{Ar}) .{ }^{13} \mathrm{C}$ NMR (100 MHz, DMSO-d 6 ) $\delta$ : $19.51\left(\mathrm{C}-\mathrm{CH}_{3}\right), 58.61\left(\mathrm{CH}_{2} \mathrm{NCH}_{2}\right), 58.83\left(\mathrm{CH}_{2} \mathrm{OCH}_{2}\right)$, $67.62\left(\mathrm{~N}-\overline{\mathrm{CH}}_{2}-\mathrm{N}\right), 117.2(\mathrm{C}), 126.8(\mathrm{C}), 127.5(\mathrm{C}), 128.3$ (C), 128.7 (2C), 130.4 (C), 131.7 (2C), 132.0 (C), 138.5 $\left(\underline{C}-\mathrm{CH}_{3}\right), 141.2(\mathrm{~N}-\mathrm{C}), 145.4(\mathrm{C}), 159.5(\mathrm{C}=\mathrm{S})$. Anal. Calcd. for $\mathrm{C}_{20} \mathrm{H}_{22} \mathrm{BrN}_{4} \mathrm{OS}, \% \mathrm{~N}$ 15.29; $\mathrm{S}$ 8.75. Found, \% N 15.4; $\mathrm{S} 8.91$.

\section{3-thione 4.7}

4,5-Diphenyl-2-(1-piperidylmethyl)-1,2,4-triazole-

Yield $63 \%$, mp 463-464 K. ${ }^{1} \mathrm{H}$ NMR $(400 \mathrm{MHz}$, DMSO-d $\left.{ }_{6}\right) \delta: 1.40\left(\mathrm{~m}, 2 \mathrm{H}, \mathrm{CH}_{2}\right), 1.55\left(\mathrm{~m}, 4 \mathrm{H}, \mathrm{CH}_{2} \mathrm{CH}_{2}\right)$, 
$2.60\left(\mathrm{~m}, 4 \mathrm{H}, \mathrm{CH}_{2} \mathrm{NCH}_{2}\right), 5.15\left(\mathrm{~s}, 2 \mathrm{H}, \mathrm{N}-\mathrm{CH}_{2}-\mathrm{N}\right), 7.20$ $7.50(\mathrm{~m}, 10 \mathrm{H}, 2 \mathrm{Ph}) .{ }^{13} \mathrm{C}$ NMR $\left(100 \mathrm{MHz}, \mathrm{DMSO}_{-} \mathrm{d}_{6}\right) \delta$ : $23.79\left(\mathrm{CH}_{2}\right), 25.95\left(\mathrm{CH}_{2} \mathrm{CH}_{2}\right), 51.45\left(\mathrm{CH}_{2} \mathrm{NCH}_{2}\right), 67.58$ $\left(\mathrm{N}-\mathrm{CH}_{2}-\mathrm{N}\right), 126.6(\mathrm{C}), 127.5(2 \mathrm{C}), 128.4(2 \mathrm{C}), 128.7$ (2C), $130.4(\mathrm{C}), 131.3(\mathrm{C}), 131.6(2 \mathrm{C}), 139.5(\mathrm{~N}-\mathrm{C})$, 145.4 (C), $159.5(\mathrm{C}=\mathrm{S})$. Anal. Calcd. for $\mathrm{C}_{20} \mathrm{H}_{22} \mathrm{~N}_{4} \mathrm{OS}, \%$ N 15.99; S 9.15. Found, \% N 16.4; S 9.41.

5-(4-Bromophenyl)-4-phenyl-2-(1-

piperidylmethyl)-1,2,4-triazole-3-thione $\mathbf{4 . 8}$

Yield $69 \%$, mp 183-184 ${ }^{\circ} \mathrm{C} .{ }^{1} \mathrm{H}$ NMR $(400 \mathrm{MHz}$, DMSO-d $\left.\mathrm{d}_{6}\right) \delta: 1.40\left(\mathrm{~m}, 2 \mathrm{H}, \mathrm{CH}_{2}\right), 1.52\left(\mathrm{~m}, 4 \mathrm{H}, \mathrm{CH}_{2} \mathrm{CH}_{2}\right)$, $2.60\left(\mathrm{~m}, 4 \mathrm{H}, \mathrm{CH}_{2} \mathrm{NCH}_{2}\right), 5.15\left(\mathrm{~s}, 2 \mathrm{H}, \mathrm{N}-\mathrm{CH}_{2}-\mathrm{N}\right), 7.25-$ $7.50\left(\mathrm{~d}-\mathrm{d}, 4 \mathrm{H}, \mathrm{C}_{6} \mathrm{H}_{4}\right) .{ }^{13} \mathrm{C}$ NMR (100 MHz, DMSO-d $\left.\mathrm{d}_{6}\right) \delta$ : $23.82\left(\mathrm{CH}_{2}\right), 26.03\left(\mathrm{CH}_{2} \mathrm{CH}_{2}\right), 51.52\left(\mathrm{CH}_{2} \mathrm{NCH}_{2}\right), 67.73$ $\left(\mathrm{N}-\mathrm{CH}_{2}-\mathrm{N}\right), 124.1(\mathrm{Br}-\mathrm{C}), 126.6(\mathrm{C}), 127.5(2 \mathrm{C}), 128.3$ (2C), 129.9 (C), 130.9 (2C), 132.4 (2C), 139.6 (2C), 145.3 (C), $159.5(\mathrm{C}=\mathrm{S})$. Anal.Calcd. for $\mathrm{C}_{20} \mathrm{H}_{21} \mathrm{BrN}_{4} \mathrm{~S}, \% \mathrm{~N}$ 13.05; S 7.47. Found, \% N 13.3; S 7.75.

5-(4-Bromophenyl)-4-(4-ethoxyphenyl)-2-(1-

piperidylmethyl)-1,2,4-triazole-3-thione 4.9

Yield $72 \%$, mp 431-432 K. ${ }^{1} \mathrm{H}$ NMR (400 MHz, DMSO-d $\left.\mathrm{d}_{6}\right) \delta: 1.40\left(\mathrm{t}, 3 \mathrm{H}, \mathrm{OCH}_{2} \mathrm{CH}_{3}\right), 1.40\left(\mathrm{~m}, 2 \mathrm{H}, \mathrm{CH}_{2}\right)$, $1.56\left(\mathrm{~m}, 4 \mathrm{H}, \mathrm{CH}_{2} \mathrm{CH}_{2}\right), 2.60\left(\mathrm{~m}, 4 \mathrm{H}, \mathrm{CH}_{2} \mathrm{NCH}_{2}\right), 4.05$ (q, $\left.2 \mathrm{H}, \mathrm{OCH}_{2} \mathrm{CH}_{3}\right), 5.15\left(\mathrm{~s}, 2 \mathrm{H}, \mathrm{N}-\mathrm{CH}_{2}-\mathrm{N}\right), 7.00-7.60(\mathrm{~m}$, $\left.8 \mathrm{H}, \mathrm{C}_{6} \mathrm{H}_{4}\right) .{ }^{13} \mathrm{C}$ NMR $(100 \mathrm{MHz}$, DMSO-d 6 ) $\delta: 14.73$ $\left(\mathrm{CH}_{3}\right), 23.85\left(\mathrm{CH}_{2}\right), 26.07\left(\mathrm{CH}_{2} \mathrm{CH}_{2}\right), 58.58\left(\mathrm{CH}_{2} \mathrm{NCH}_{2}\right)$, $63.59\left(\mathrm{OCH}_{2}\right), 67.85\left(\mathrm{~N}-\mathrm{CH}_{2}-\mathrm{N}\right), 115.2(2 \mathrm{C}), 124.1(\mathrm{Br}-$ C), 130.0 (C), 130.5 (2C), 130.9 (2C), 132.6 (2C), 133.7 (N-C), $145.4(\mathrm{C}), 154.8(\mathrm{C}-\mathrm{O}), 159.3(\mathrm{C}=\mathrm{S})$. Anal. Calcd. for $\mathrm{C}_{22} \mathrm{H}_{25} \mathrm{BrN}_{4} \mathrm{OS}, \% \mathrm{~N}$ 11.83; $\mathrm{S}$ 6.77. Found, \% N 11.9; S 6.89 .

5-Phenyl-4-(m-tolyl)-2-(1-piperidylmethyl)-1,2,4triazole-3-thione $\mathbf{4 . 1 0}$

Yield $66 \%$, mp 443-445 K. ${ }^{1} \mathrm{H}$ NMR $(400 \mathrm{MHz}$, DMSO- $\left.\mathrm{d}_{6}\right) \delta: 1.40\left(\mathrm{~m}, 2 \mathrm{H}, \mathrm{CH}_{2}\right), 1.55\left(\mathrm{~m}, 4 \mathrm{H}, \mathrm{CH}_{2} \mathrm{CH}_{2}\right)$, $2.34\left(\mathrm{~s}, 3 \mathrm{H}, \mathrm{CH}_{3}\right), 2.64\left(\mathrm{~m}, 4 \mathrm{H}, \mathrm{CH}_{2} \mathrm{NCH}_{2}\right), 5.15(\mathrm{~s}, 2 \mathrm{H}$, $\left.\mathrm{N}-\mathrm{CH}_{2}-\mathrm{N}\right), 7.10-7.45(\mathrm{~m}, 9 \mathrm{H}, \mathrm{Ar}) .{ }^{13} \mathrm{C}$ NMR $(100 \mathrm{MHz}$, DMSO-d $\left.{ }_{6}\right) \delta$ : $19.48\left(\mathrm{CH}_{3}\right), 23.85\left(\mathrm{CH}_{2}\right), 26.03\left(\mathrm{CH}_{2} \mathrm{CH}_{2}\right)$, $51.51\left(\mathrm{CH}_{2} \mathrm{NCH}_{2}\right), 67.71\left(\mathrm{~N}-\mathrm{CH}_{2}-\mathrm{N}\right), 117.3(\mathrm{C}), 126.8$ (C), 127.6 (C), 128.2 (C), 128.8 (2C), 130.3 (C), 131.7 (2C), $132.0(\mathrm{C}), 138.5\left(\underline{\mathrm{C}}-\mathrm{CH}_{3}\right), 141.3(\mathrm{~N}-\mathrm{C}), 145.3(\mathrm{C})$, $159.4(\mathrm{C}=\mathrm{S})$. Anal. Calcd. for $\mathrm{C}_{21} \mathrm{H}_{24} \mathrm{~N}_{4} \mathrm{~S}, \% \mathrm{~N}$ 15.37; S 8.80. Found, \% N 15.5; $\mathrm{S} 8.93$.

\subsection{Molecular Docking Method}

The Scigress Explorer, 7.7 (Fujitsu, Fukuoka, Japan (License number 742F6852C191) software was used for the screening. The software was set on the computer with the frequency of $3.4 \mathrm{~Hz}$, an Intel Core 2 Duo $1 \mathrm{~Gb}$ RAM processor and a $160 \mathrm{~Gb}$ hard drive with the Windows XP system.

The ISIS Draw 4.0 software tool was employed in the present research; the chemical structures of ten new substances were saved as .mol files. Then, the structures were imported to the SCIGRESS program and saved in .csf format.

The following parameters of docking were determined: translational motion step was equal to $2 \AA$, quaternion angle $50^{\circ}$, torsion angle $50^{\circ}$. Torsion degree of freedom and coefficient were 2 and 0.274 , respectively; cluster tolerance $2 \AA$; external lattice energy 1000 , maximal initial energy 0 , maximal number of attempts 10000; number of structures in the population 300 , maximal number of stages of energy evaluation 850000 , maximal number of generations 27000, number of structures passing to the next generation 1 , level of gene mutation 0.02 , level of crossover 0.8 , way of crossover was arithmetic. $\alpha$-Parameter of Gaussian distribution was equal to 0 , and $\beta$-parameter of Gaussian distribution was 1 ; number of interactions of the Lamarckian genetic algorithm was 50 for each ligand. Visual analysis of the complexes of compounds from the active site of angiotensin converting enzyme (PDB ID : 1R4L, 3NXQ, 4BZR) and angiotensin receptor was performed using Discovery Studio Visualizer 4.0 program [19].

\subsection{GUSAR-Prognosis}

To perfome the computer prognosis of acute rat toxicity of compounds using the online program Acute Rat Toxicity of the GUSAR software package of the Way2Drug web service [20]. Toxicity was predicted by the structural formula of the compounds.

\section{Results and Discussion}

The target compounds 4.1-4.10 were obtained as a result of a one-pot multicomponent Mannich reaction. The synthesis was carried out by interaction of substrates containing active hydrogen - substituted 1,2,4-triazole-3thiones 1.1-1.10, secondary amine (morpholine or piperidine) $\mathbf{2}$ and $\alpha$-CH-acidic compound (nucleophile) formaldehyde 3 in ethanol medium (Scheme 1).

The reaction proceeds via the formation of immonium salt, which subsequently attacks the $\mathrm{N}^{2}$ atom of triazole giving rise to a regioselective Mannich base. It should be noted that the reaction is highly regioselective and furnishes only the N-Mannich base although the intermediate Schiff base can exist in the thiol-thione tautomeric equilibrium.

It is important to note that Mannich bases with yields of $63-76 \%$ were obtained at room temperature for $12 \mathrm{~h}$ with pre-stirring of the reaction mixture for $1 \mathrm{~h}$.

The synthesized Mannich bases 4.1-4.10 are products of substitution of active hydrogen in position 2 of the 1,2,4-triazole cycle for the remainder of morpholine or piperidine. The formation of the Mannich bases was confirmed by the data of ${ }^{1} \mathrm{H}$ NMR and ${ }^{13} \mathrm{C}$ NMR-spectra. 




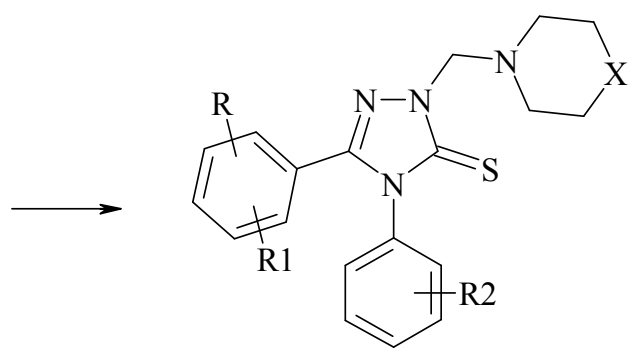

4.1-4.10
4.1 $\mathrm{R}=\mathrm{R} 1=\mathrm{R} 2=\mathrm{H}, \mathrm{X}=\mathrm{O}$

4.2 $\mathrm{R}=4-\mathrm{Br} ; \mathrm{R} 1=\mathrm{H} ; \mathrm{R} 2=\mathrm{H}, \mathrm{X}=\mathrm{O}$

$4.3 \mathrm{R}=4-\mathrm{Bn} ; \mathrm{R} 1=\mathrm{H} ; \mathrm{R} 2=\mathrm{H}, \mathrm{X}=\mathrm{O}$

4.4 $\mathrm{R}=4-\mathrm{Br} ; \mathrm{R} 1=\mathrm{H} ; \mathrm{R} 2=4-\mathrm{OC}_{2} \mathrm{H}_{5}, \mathrm{X}=\mathrm{O}$

$4.5 \mathrm{R}=2-\mathrm{Cl} ; \mathrm{R} 1=4-\mathrm{Cl} ; \mathrm{R} 2=\mathrm{H}, \mathrm{X}=\mathrm{O}$

4.6 $\mathrm{R}=\mathrm{H} ; \mathrm{R} 1=\mathrm{H} ; \mathrm{R} 2=3-\mathrm{CH}_{3}, \mathrm{X}=\mathrm{O}$

4.7 $\mathrm{R}=\mathrm{R} 1=\mathrm{R} 2=\mathrm{H}, \mathrm{X}=\mathrm{CH}_{2}$

4.8 $\mathrm{R}=4-\mathrm{Br} ; \mathrm{R} 1=\mathrm{H} ; \mathrm{R} 2=\mathrm{H}, \mathrm{X}=\mathrm{CH}_{2}$

4.9 $\mathrm{R}=4-\mathrm{Br} ; \mathrm{R} 1=\mathrm{H} ; \mathrm{R} 2=4-\mathrm{OC}_{2} \mathrm{H}_{5}, \mathrm{X}=\mathrm{CH}_{2}$

4.10 $\mathrm{R}=\mathrm{H} ; \mathrm{R} 1=\mathrm{H} ; \mathrm{R} 2=3-\mathrm{CH}_{3}, \mathrm{X}=\mathrm{CH}_{2}$

\section{Scheme 1}

Table 1

The indices of the Mannich bases acute toxicity calculated using online program Acute Rat Toxicity of the GUSAR software package of the Way2Drug web service

\begin{tabular}{|c|c|c|c|c|}
\hline \multirow{2}{*}{ Compound } & \multicolumn{4}{|c|}{ Route of administration, $\mathrm{LD}_{50}, \mathrm{mg} / \mathrm{kg}$} \\
\cline { 2 - 5 } & Intra-abdominal & Intravenous & Oral & Subcutaneous \\
\hline $\mathbf{4 . 1}$ & 513.5 & 115.8 & 1542.0 & 868.0 \\
\hline $\mathbf{4 . 2}$ & 707.0 & 116.0 & 1415.0 & 2900.0 \\
\hline $\mathbf{4 . 3}$ & 613.0 & 99.8 & 1767.0 & 438.2 \\
\hline $\mathbf{4 . 4}$ & 889.7 & 66.2 & 1104.0 & 1589.0 \\
\hline $\mathbf{4 . 5}$ & 1025.0 & 48.9 & 1233.0 & 1253.0 \\
\hline $\mathbf{4 . 6}$ & 568.0 & 81.7 & 1097.0 & 666.9 \\
\hline $\mathbf{4 . 7}$ & 365.4 & 68.8 & 562.9 & 472.4 \\
\hline $\mathbf{4 . 8}$ & 677.0 & 72.2 & 923.4 & 1271.0 \\
\hline $\mathbf{4 . 9}$ & 556.2 & 47.0 & 1080.0 & 5 \\
\hline $\mathbf{4 . 1 0}$ & 324.4 & 50.2 & & 40.3 \\
\hline
\end{tabular}

The analysis of ${ }^{13} \mathrm{CNMR}$-spectra of compounds showed a characteristic signal of the Carbon atom involved in the formation of the $\mathrm{C}=\mathrm{S}$ bond at $\delta=151.2-159.5 \mathrm{ppm}$. In the ${ }^{1} \mathrm{H}$ NMR spectra of all compounds synthesized there was no hydrogen proton signal in position 2 of the 1,2,4triazole cycle, and there were signals of the $\mathrm{N}-\mathrm{CH}_{2}-\mathrm{N}$ group at $\delta=5.02-5.15 \mathrm{ppm}$. The analysis of ${ }^{1} \mathrm{H}$ NMRspectra of morpholine-containing 4,5-disubstituted 1,2,4triazole-3-thiones 4.1-4.6 showed signals as multiplets of the $\mathrm{CH}_{2} \mathrm{OCH}_{2}$ oxygen-containing morpholine group at $\delta=3.55-3.64 \mathrm{ppm}$, of the $\mathrm{CH}_{2} \mathrm{NCH}_{2}$ nitrogen-containing morpholine group at $\delta=2.60-3.02 \mathrm{ppm}$, and general resonance signals of aromatic protons in positions 4 and 5 of the 1,2,4-triazole cycle at $6.80-7.60 \mathrm{ppm}$ as multiplets. The analysis of ${ }^{1} \mathrm{H}$ NMR-spectra of piperidine-containing 4,5-disubstituted 1,2,4-triazole-3-thiones 4.7-4.10 showed signals as multiplets of the piperidine groups at $\delta=1.40 \mathrm{ppm}\left(\mathrm{CH}_{2}\right), \delta=1.52-1.56 \mathrm{ppm}\left(\mathrm{CH}_{2} \mathrm{CH}_{2}\right)$, $\mathrm{C}_{2} \mathrm{NC}_{2}$ group at $\delta=2.60-2.64 \mathrm{ppm}$, and general resonance signals of aromatic protons at $7.00-7.60 \mathrm{ppm}$ as multiplets.

The data obtained reliably confirmed the aminomethylation reaction with the formation of Mannich $\mathrm{N}$-bases.

To optimize the pharmacological screening of Mannich N-bases synthesized, computer prognosis of 
acute rat toxicity was carried out using online program Acute Rat Toxicity of the GUSAR software package.

The results of computer prognosis (Table 1) indicates that the compounds synthesized probably belong to the toxicity class 4 and 5 according to the classification of chemicals by the OECD project (substances are lowtoxic and practically non-toxic).

The docking studies for ten new substances of 1,2,4-triazole derivatives containing the morpholine or piperidine moiety 4.1-4.10 were performed.

The choice of a biological target was stipulated by the literature data concerning the mechanism of action of the known antihypertensive drugs. The renin-angiotensin system is one of the most important regulatory system of the cardiovascular and renal function. The renin-angiotensin system blockade exerts potent antiatherosclerotic effects mediated by their antihypertensive, anti-inflammatory, antiproliferative, and oxidative stress lowering properties. Inhibitors of the system, angiotensin converting enzyme inhibitors, are now first-line treatments for the hypertensive target organ damage and progressive renal disease. Their effects are greater than expected by their ability to lower blood pressure alone. Although significant advances have been made in the therapeutic blockade of the renin-angiotensin-aldosterone system (RAAS or RAS), the use of angiotensin-converting enzyme (ACE) inhibitors, angiotensin receptor blockers and non-selective aldosterone receptor antagonists, there is a clear need for both additional blocking strategies and enhancements of the current therapeutic approaches [21].

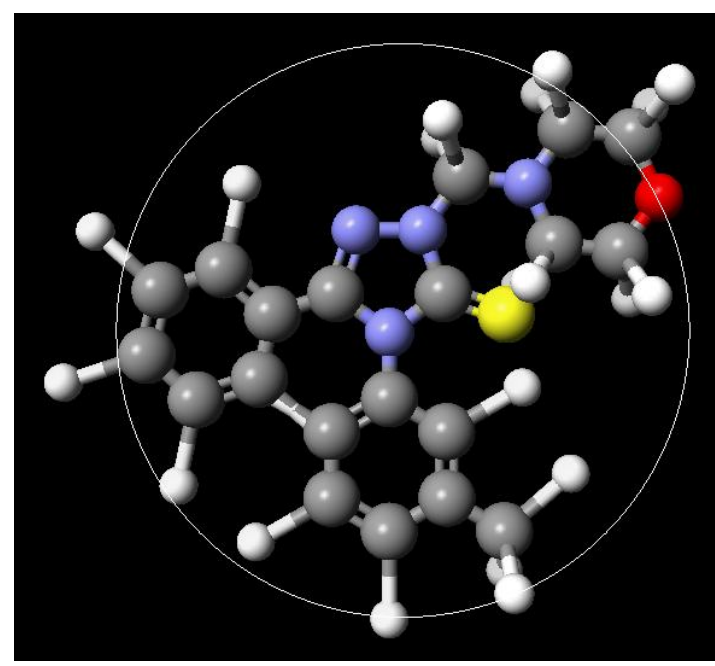

a)
The active sites of the macromolecules from Protein Data Bank (PDB) of the angiotensin converting enzyme (PDB ID : 1R4L, 3NXQ, 4BZR) were chosen as biological targets for docking [22-24].

The structures of ten new substances in .csf format are presented in Fig. 1a.

The next stage was 3D optimization of geometry of the structures mentioned using the molecular mechanics MM3 method. Optimization of the molecules was performed using the MO-G function calculating and minimizing the energy associated with the heat formation (Fig. 1b). The molecular mechanics MM3 method for optimization of molecules to the lowest steady energy stage was used.

All chemical structures of ten new substances of 1,2,4-triazole derivatives containing the morpholine or piperidine moiety were docked into the active centers of the crystalline structures using the Dock into active site function. Molecules of water from PDB file ID: 1R4L, $3 \mathrm{NXQ}, 4 \mathrm{BZR}$ were removed. The genetic algorithm was used within automatic docking. The use of the genetic algorithm allows to study all area available for the ligand by parameters.

As a result of the molecular docking, a number of the consensus scoring function values estimating the quality and binding energy of the substances studied with the molecules of biological targets was obtained.

The best affinity binding was observed in the case of molecules with the crystallographic model of the angiotensin-converting enzyme PDB ID: 1R4L. The results of the calculations are presented in Table 2 .

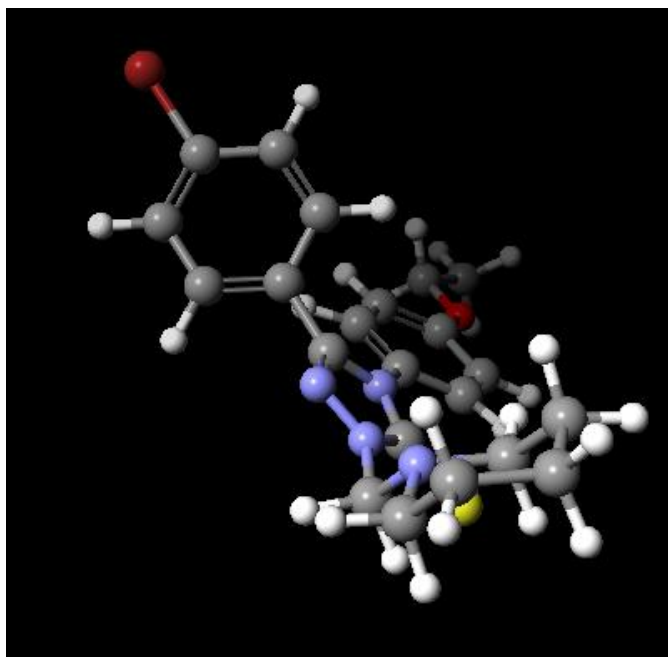

b)

Fig. 1. 2-(Morpholinomethyl)-4-( $m$-tolyl)-5-phenyl-1,2,4-triazole-3-thione 4.6 chemical structure in.3D .csf format (a) and its 3D optimization using MM3 method (b) 
The range of values of the calculated scoring functions for the compounds synthesized

\begin{tabular}{|c|c|c|c|}
\hline \multirow{2}{*}{ Compound } & \multicolumn{3}{|c|}{ PDB ID } \\
\cline { 2 - 4 } & 1R4L & 3NXQ & 4BZR \\
\hline $\mathbf{4 . 1}$ & -5.50 & -2.90 & -1.16 \\
\hline $\mathbf{4 . 2}$ & -6.03 & -2.29 & -2.17 \\
\hline $\mathbf{4 . 3}$ & -6.61 & -3.80 & -1.98 \\
\hline $\mathbf{4 . 4}$ & -5.16 & -1.88 & -1.16 \\
\hline $\mathbf{4 . 5}$ & -5.33 & -1.51 & -2.05 \\
\hline $\mathbf{4 . 6}$ & -7.66 & -1.44 & -3.36 \\
\hline $\mathbf{4 . 7}$ & -2.40 & -2.50 & -2.92 \\
\hline $\mathbf{4 . 8}$ & -2.50 & -3.52 & -3.90 \\
\hline $\mathbf{4 . 9}$ & -2.30 & -2.20 & -1.88 \\
\hline $\mathbf{4 . 1 0}$ & -2.40 & -3.80 & -2.80 \\
\hline Ligand- comparison & -4.10 & -4.90 & \\
\hline
\end{tabular}



Fig. 2. 2-(Morpholinomethyl)- 4-( $m$-tolyl)-5-phenyl1,2,4-triazole-3-thione $\mathbf{4 . 6}$ in the active site $1 \mathrm{R} 4 \mathrm{~L}$

Complexes of practically all compounds tested with the angiotensin converting enzyme PDB ID : 1R4L receptor gave higher absolute values of scoring functions compared to other targets (3NXQ, 4BZR). This is the evidence of the higher thermodynamic probability manifestation of the blocking activity of compounds into this target. It should be noted that among two groups of the substances studied all six compounds containing the morpholine fragment in the structure had the highest absolute values of scoring functions in the formation of complexes of substances with the angiotensin-converting enzyme 1R4L.

The analysis of the geometric arrangement of the substances synthesized in the active site of the angiotensin converting enzyme 1R4L showed that $\pi-\pi$ interactions were formed between both aromatic phenyl rings of the molecules with Phe274 amino acid residues; $\pi$-Alk and Alk interactions occurred with the participation of phenyl ring, as well as Phe274 and Arg 273 amino acid residues. Conventional hydrogen bonds were formed by a Sulfur



A:SN $: 149$
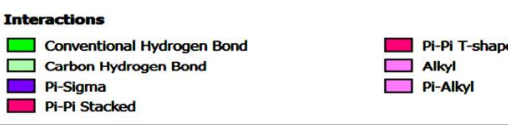

Fig. 3. Diagrams of interaction of lead compounds 4.6 in complexes: with 1R4L

atom of molecules, and Tyr 371 and Asp 368 amino acid residues. The molecules 4.1-4.6 formed more stable complexes with the angiotensin converting enzyme due to the additional $\pi$-alkyl bonding of the morpholine fragment with Pro 346 residues and the hydrogen bond with Asn 149 and Cys 361 (Fig. 2).

Thus, the highest affinity with the angiotensinconverting enzyme (PDB ID : 1R4L) was observed in the case of a lead compound 4.6 - 2-(morpholinomethyl)-4- $(m-$ tolyl)-5-phenyl-1,2,4-triazole-3-thione $(E d o c=-31.8 \mathrm{~kJ} / \mathrm{mol})$ (Fig. 3).

Thus, the inhibitory activity of the test compounds relative to angiotensin-converting enzyme can be manifested through the formation of complexes between them. The stability of these complexes is provided mainly by the energy-favorable geometric arrangement of ligands at the active site of the acceptor and the formation of hydrogen bonds between them by intermolecular electrostatic and donor-acceptor interactions. 


\section{Conclusions}

Non-described in literature Mannich bases - 4,5disubstituted 1,2,4-triazole containing morpholine and piperidine moiety have been synthesized. The structure and purity of target compounds have been confirmed by ${ }^{1} \mathrm{H}$ NMR, ${ }^{13} \mathrm{C}$ NMR-spectroscopy and elemental analysis. All compounds synthesized probably belong to low-toxic and practically non-toxic substances, and, therefore, can be recommended for experimental biological tests. The docking studies of the compounds synthesized relative to proteins of the angiotensin-converting enzyme (PDB ID : 1R4L, 3NXQ, 4BZR) have shown that all compounds have affinity for these biological targets and are promising objects for pharmacological screening for antihypertensive activity. It has been found that compounds synthesized have the highest absolute value of scoring relative to the protein of the angiotensin-converting enzyme (PDB ID : 1R4L). This is the evidence of higher thermodynamic probability manifestation of the compounds blocking activity.

\section{References}

[1] Kang D., Fang Z., Huang B. et al.: Chem. Biol. Drug Design, 2015, 86, 568. https://doi.org/10.1111/cbdd.12520

[2] Drapak I., Zimenkovsky B., Perekhoda L. et al.: Pharmacia, 2019, 66, 33. https://doi.org/10.3897/pharmacia.66.e35083

[3] Ueda Y., Timothy P., Wang I. et al.: Pat. US 8461333 B2, Publ. Jun. 11, 2013.

[4] Yradjan M., Yradjan N., Paronykjan R., Stepanjan H.: KhimikoFarmacevt. Zh., 2010, 44, 11.

[5] Klen E., Makarova N., Chalyullyn F. et al.: Bashkirsky Khim. Zh., 2008, 15, 112

[6] Jakhmola V., Jawla S., Mishra R.: Acta Sci. Pharm. Sci., 2018, 2, 02.

[7] Al-Ghorbani M., Begum B. et al.: J. Chem. Pharm. Res., 2015,

8, 611. https://doi.org/10.5958/0974-360X.2015.00100.6

[8] Kourounakis A., Xanthopoulos D., Tzara A.: Med. Res. Rev., 2020, 40, 709. https://doi.org/10.1002/med.21634

[9] Yan X., Wang Z., Qi P. et al.: Eur. J. Med. Chem., 2019, 177, 425. https://doi.org/10.1016/j.ejmech.2019.05.056

[10] Ladopoulou E., Matralis A., Nikitakis A., Kourounakis A.:

Bioorg. Med. Chem., 2015, 23, 7015.

https://doi.org/10.1016/j.bmc.2015.09.034

[11] Mytnyk Z., Kolesnyk Ju.: Zaporozhsky Med. Zh., 2010, 12, 79.
[12] Bhat M., Al-Omar M., Ghabbour H., Naglah A.: Molecules, 2018, 23, 1559. https://doi.org/10.3390/molecules23071559

[13] Manjusha R., Begum S., Begum A., Bharathi K.: Asian J. Pharm. Clinical Res., 2018, 11, 66.

https://doi.org/10.3390/molecules23071559

[14] Kaplaushenko A.: Naukovyi Zh. MOZ Ukrainy, 2013, 3, 152.

[15] Sahu N., Sahu J., Kaushik A.: Curr. Res. Pharm. Sci., 2013, 3, 108.

[16] Malani A., Makwana A., Makwana H.: Moroccan J. Chem., $2017, \mathbf{5}, 41$.

[17] Liu J., Liu Q., Yang X. et al.: Bioorgan. Med. Chem., 2013, 21, 7742. https://doi.org/10.1016/j.bmc.2013.10.017

[18] Zhou C.-H., Wang Y.: Current Medicinal Chemistry, 2012, 19, 239. https://doi.org/10.2174/092986712803414213

[19] http://accelrys.com/

[20] http://www.way2drug.com/gusar/acutoxpredict.html

[21] Drapak I., Suleiman M., Protopopov M. et al.: Res. J. Pharm. Technol., 2019, 12, 4889. https://doi.org/10.5958/0974-

360X.2019.00846.1

[22] Anthony C., Corradi H., Schwager S. et al.: J. Biol. Chem., 2010, 285, 35685. https://doi.org/10.1074/jbc.M110.167866

[23] Kramer G., Mohd A., Schwager S. et al.: ACS Med. Chem. Lett., 2014, 5, 346. https://doi.org/10.1021/ml4004588

[24]

http://www.fda.gov/drugs/drugsafety/postmarketdrugsafetyinformati onforpatientsandproviders/ucm102981.htm

Received: June 06, 2019 / Revised: August 08, 2019 / Accepted: September 12, 2019

\section{СИНTE3 TA IN SILICO ПРОГНОЗ АНТИГІПЕРТЕНЗИВНОЇ АКТИВНОСТІ НОВИХ ОСНОВ МАННІХА, ЩО МІСТЯТЬ ФРАГМЕНТ 1,2,4-ТРІАЗОЛУ}

Анотація. У рамках наших постійних досліджень щодо потенційних антигіпертензивних агентів серед похідних морфоліну та піперидину було розроблено та синтезовано 10 нових иільових сполук, що містять 1,2,4-тріазольний та морфоліновий або піперидиновий фрагменти. Проведені докінгові дослідження з метою пошуку біологічно активних речовин антигіпертензивної дї. Результати in silico досліджень свідчать, що всі синтезовані сполуки є перспективними інгібіторами ангіотензинперетворюючого ферменту і належать до 4 та 5 класів токсичності згідно класифікачиї ОЕСР.

Ключові слова: основи Манніха, 1,2,4-тріазол, синтез, антигіпертензивна активність, прогноз in silico, докінгові дослідження. 